\title{
INTEGRATED APPROACH IN THE PLANNING STAGE FOR LANDSCAPE CONSERVATION IN THE COASTAL ITALIAN AREAS
}

\author{
D. CIALDEA \& L. MASTRONARDI \\ Di.B.T. Department Laboratorio L.a.co.s.t.a. University of Molise, Italy.
}

\begin{abstract}
This paper analyzes the relationships between 'biodiversity conservation' and 'landscape quality aims' in the coastal area of the Molise Region in Italy, in order to provide useful tools for spatial planning choices. The fine-tuning of our methodology is the result of the substantial experience in research matured by the L.a.co.s.t.a. laboratory. Our research on regional coastal territory as embodied in the GES.S.TER Project, through the use of GIS software for spatial analysis, wants to reconstruct the main changes in the geography of the coastal zone such as the change of the coastline, variations in the river mouths and stretches of coastline erosion. It also wants to investigate major changes due to the settlement of the territory along the coast especially in relation to tourism activities.

Keywords: Coastal areas, environment, landscape, planning activities, water issues.
\end{abstract}

\section{INTRODUCTION}

The strategical relevance of coastal areas-in social, economic and environmental fields-is strictly connected to biophysical and anthropogenic problems [1] that have an impact on the landscape, especially for the conservation of resources and biodiversity [2].

The Mediterranean's coastal areas are subjected to a set of pressures and to a serious degradation of its resources [3], mainly due to a significant and non-coherent urban development, but also to a large land-based pollution and to activities, such as tourism [4-6]. In summary, the main issues affecting the coastal areas can be linked to: 1) urbanization and infrastructures; 2) density of population; 3) erosion; 4) salinization of groundwater; 5) climate change; 6) widespread pollution; 7) loss of biodiversity.

Landscape is a factor of reorganization and territorial competitiveness [7-8] which creates ecological, environmental, cultural, social and economic values [9], through which it is possible to recognize and recover the identity of places [10] and, in this way, it represents a tool to design a model of integrated and sustainable territorial development. For this purpose, the European Commission promotes an integrated management of the coastal areas (GIZC), to be intended as a dynamic, interdisciplinary and interactive process aimed at promoting a sustainable structure of the coastal areas.

Integrated coastal management is a tool for the integrated management of all policy processes affecting the coastal zone, addressing land-sea interactions of coastal activities in a coordinated way with a view to ensuring the sustainable development of coastal and marine areas. It ensures that management or development decisions are taken coherently across sectors. A 2002 Recommendation on Integrated Coastal Zone Management defines the principles of sound coastal planning and management and how to best implement them. The EU is also a contracting party to the Barcelona Convention, which established a Protocol on Integrated coastal management that entered into force in March 2011. This Protocol makes integrated coastal management compulsory for Member States bordering the Mediterranean Sea. 


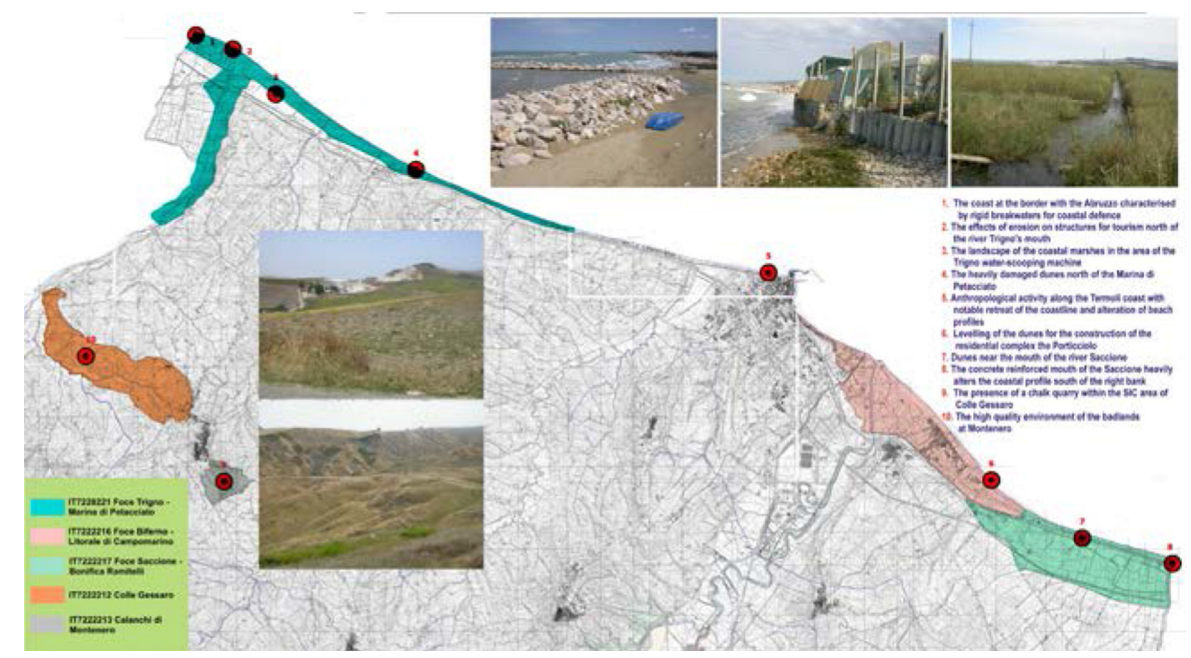

Figure 1: Environmental condition along the coastal S.I.C (Source: C.T.R. Molise, our elaboration).

Within this context, the paper sheds light on the relation between 'biodiversity conservation' and 'landscape quality aims' in the coastal area of the Molise Region in Italy (Fig.1) and for this purpose a methodology for reading the interconnections between human factors (demographic and economic) and spatial ones (landscape and nature) is developed, in order to define a useful contribution for planning, especially for landscape planning.

The area hosts natural situations worthy of conservation, as evidenced by the presence (total or partial) of well 5 Sites of Community Importance (SCI) containing habitats belonging to wetlands, riparian and coastal zones and gullies, as well as a fair number of animal species, mainly birds, and two vegetal species of primary interest [11]. Interesting from a historical and cultural point of view is the presence of well 2 'tratturi', that is the routes crossed by transhumance.

The area shows a good level of development [12] and of socio-economic and territorial integration [13], which involved all the regional landscape, except the inner areas [14]. The area also shows a significant level of tourism development, even if it is tourism of domestic and hiking type [15].

\section{THE RESEARCH METHODOLOGY}

An analysis of demographic, economic and tourism dynamics was carried out in order to focus on the changes which have been recorded in our sample area.

In this regard, the investigated dimensions are the following: 1) population; 2) dwellings; 3) agriculture; 4) industry and services; 5) tourism.

Our research on regional coastal territory as embodied in the GES.S.TER Project, through the use of GIS software for spatial analysis, wants to reconstruct the main changes in the geography of the coastal zone such as changes of the coastline, variations in the river mouths and stretches of coastline erosion. It also wants to investigate major changes due to the settlement of the territory along the coast especially in relation to economic factors.

The information sources used for the statistical elaborations are mainly based on data by ISTAT (Central Institute of Statistics) and they are basically census data. The analytical system concerned, first of all, the construction of 'integrated signs', that is the main changes occurred between the first 
and the last reference year (year 2011), in relation to the investigated phenomena. In this case, the adopted methodologies are the usual ones for the analysis of structural changes and they don't require specific explanations. Afterwards, the analysis regarded the study of the relations which exist between social, economic and territorial phenomena to identify the cases with the greatest impact on landscape and nature and for this purpose was carried out an econometric analysis which allowed to summarize the modes of interaction. In relation to this, the analysis made use of a set of 50 indicators, taken mainly from literature on the evaluation of environmental impacts in the coastal areas [16-21].

The investigated phenomena (macro-determinants) are: 1) the demographic system; 2) the economic system (agriculture, industry and services); 3) the tourism system; 4) landscape and natural elements.

The complete scheme of the indicators used in the analysis is shown in Table 1.

The methodology used for the data analysis is the Canonical Correlation Analysis-CCA [22] which can be considered a general case of multiple regression, correspondence analysis and discriminant analysis.

The objective of the CCA is to identify the linear relations which exist between two groups of quantitative variables observed on the same set of elements, in order to maximize the degree of correlation between the variables of the groups.

For a better interpretation of the results, firstly it was carried out a Principal Components Analysis (PCA) on a correlation matrix linked only to the indicators of the environmental system, in order to identify the dominant relations between the indicators in the coastal areas. Subsequently, the environmental indicators were compared to the indicators which explain the investigated macro-phenomena (demographic, economic and tourism system) according to the methodology described before (CCA) in order to bring out the situations of greater pressure on natural, seminatural, agro-environmental ecosystems and on landscape.

\section{THE LANDSCAPE QUALITY AIMS AND TERRITORIAL CHANGES}

In Italy the National Code of Cultural Heritage and Landscape was issued in 2004; following this enactment and its subsequent amendments also the Molise Region must adapt its previous landscape planning and identify the landscape quality aims for each identity area. Therefore, the landscape planning should not only interested in the preservation and conservation of the constituent elements of those parts of the territory are deemed exceptional but should be able to define lines of development and landscape quality aims for the entire territory. Objective of the plan will therefore also the identification of measures for the rehabilitation of areas affected and degraded and the identification of the lines of urban development and construction, on the basis of their compatibility with the landscape values recognized and protected, with particular attention to the protection of rural landscapes and sites inscribed on the world Heritage List of UNESCO [23].

We therefore developed a method of analysis that aims to define the territory of such landscape quality objectives. The territory was analyzed through two types of analysis: the analysis of the persistence and the diachronic analysis of changes in land-use [24,25].

With regard to the analysis of the persistence we generated a grid that is the reference for the analysis of the present state that was developed from the actual PTPAAV (Vast Area Landscape Environmental Physical Plan) and describes the zones with elements of value recognised by the landscape plan itself. In fact, it describes the elements of historical-archaeological value, visual value, productive-agricultural value, natural value and geological risk.

For what concerns, instead, the diachronic analysis of the evolution of the use of the soil, a 'grid' relative to the 'evolved state' has been generated (Fig. 2). 
Table 1: The indicator's description.

\begin{tabular}{|c|c|c|}
\hline Field & Indicator & Name \\
\hline \multirow[t]{5}{*}{ Population } & $\mathrm{P} 1$ & Number of residents \\
\hline & $\mathrm{P} 2$ & Demographic density \\
\hline & P3 & $\%$ residents in urban centers \\
\hline & $\mathrm{P} 4$ & $\%$ residents in geographical districts \\
\hline & P5 & $\%$ residents in scattered house \\
\hline \multirow[t]{5}{*}{ Dwellings } & P6 & $\%$ occupied dwellings \\
\hline & P7 & $\%$ unoccupied dwellings \\
\hline & P8 & $\%$ surface dwellings occupied by residents \\
\hline & P9 & $\%$ surface dwellings unoccupied by residents \\
\hline & $\mathrm{P} 10$ & Average dimension of dwellings \\
\hline \multirow[t]{5}{*}{ Agriculture } & E1 & Number of farms \\
\hline & E2 & Average farm size (total agricultural area/farms) \\
\hline & E3 & Total agricultural area/ total area \\
\hline & E4 & Utilized agricultural area/ total agricultural area \\
\hline & E5 & $\%$ agricultural employees \\
\hline \multirow{3}{*}{$\begin{array}{l}\text { Industry and } \\
\text { services }\end{array}$} & E6 & Local Units \\
\hline & E7 & $\%$ employees industry \\
\hline & E8 & $\%$ employees services \\
\hline \multirow[t]{22}{*}{ Tourism } & L1 & No. accommodations \\
\hline & $\mathrm{L} 2$ & No. beds \\
\hline & L3 & No. beds/No. accommodations \\
\hline & L4 & No. beds /No. hotels \\
\hline & L5 & No. beds/No. non-hotel accommodations \\
\hline & L6 & No. beds/residents \\
\hline & L7 & (No. beds/residents) $* 1 /$ land area \\
\hline & L8 & No. beds/residents x 100 inhabitants \\
\hline & L9 & $\%$ second houses \\
\hline & L10 & $\%$ beds in hotel \\
\hline & L11 & $\%$ beds in non-hotel accommodations \\
\hline & L12 & $\%$ beds in agritourism (on non-hotel ones) \\
\hline & L13 & $\%$ beds in camping sites and holiday villages (on non-hotel ones) \\
\hline & L14 & $\%$ beds tourism and hotel residences (on non-hotel ones) \\
\hline & L15 & $\%$ beds in holiday houses (on non-hotel ones) \\
\hline & L16 & $\%$ beds in B\&B (on non-hotel ones) \\
\hline & L17 & Number bathing facilities \\
\hline & L18 & Average dimension of bathing facilities \\
\hline & L19 & Surface bathing facilities \\
\hline & L20 & Average dimension of camping sites \\
\hline & $\mathrm{L} 21$ & Camping sites surface \\
\hline & $\mathrm{L} 22$ & Harbour surface \\
\hline
\end{tabular}




\begin{tabular}{lcl}
\hline Field & Indicator & Name \\
\hline Naturalistic & T1 & \% areas included in Nature 2000 Network \\
character & T2 & \% Corine areas of natural and semi-natural classes \\
& T3 & Development index of the hydrographic net \\
& T4 & $\%$ areas affected by directive (CE 43/92) habitats \\
& T5 & $\%$ areas affected by priority directive habitats \\
& T6 & \% surface largest homogenous natural forest (CLC III level) \\
& T7 & Contribution to landscape diversity (evenness) of natural types \\
& T8 & \% IB min, 1 = max] \\
& T9 & Index of intensity in agricultural use of soil \\
& T10 & $\%$ conserved sheep track surface \\
\hline
\end{tabular}

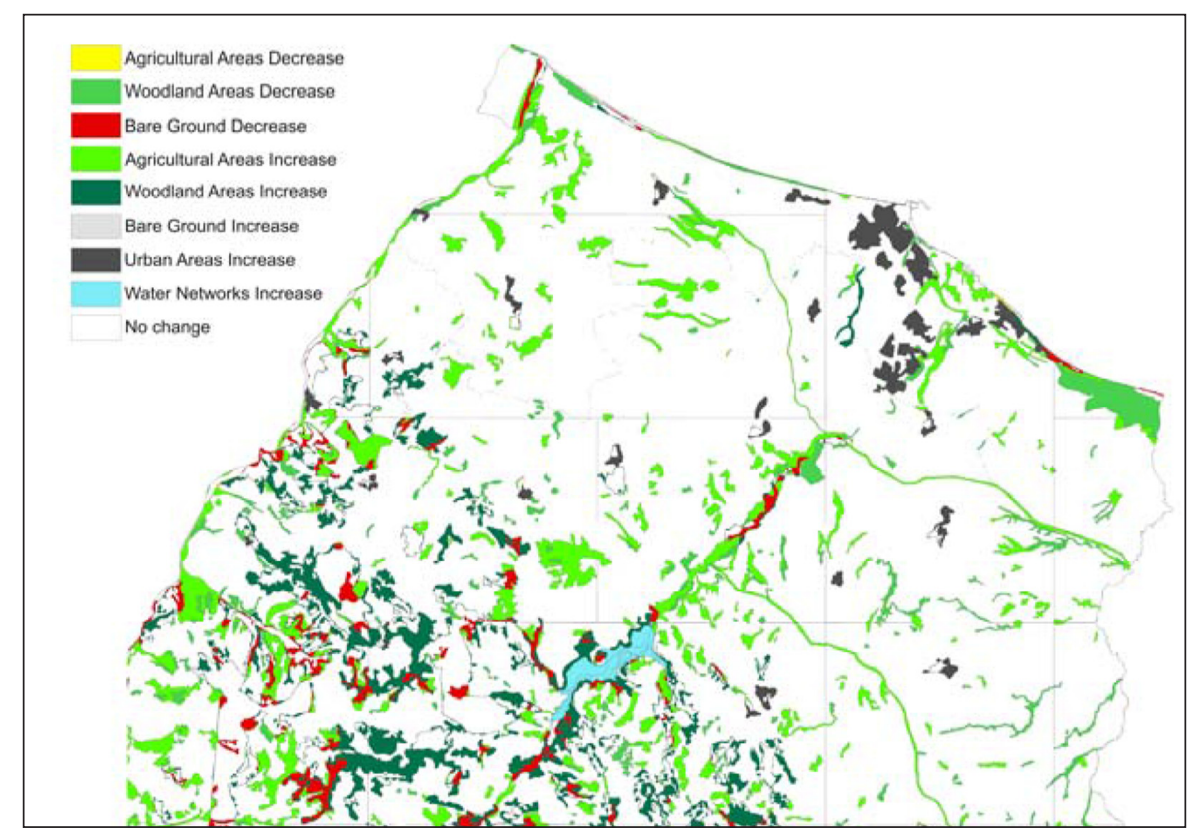

Figure 2: Land Use Map with changes from 1954 to 2006 (Source: Molise Vegetation Map, Corine Land Cover, our elaboration).

It was created on the basis of land use in the area examined in the period of time between the 1954 and the 2006: this grid highlights the main variations with particular attention to wooded areas (highlighting the areas corresponding to reforestation and deforestation), dunal areas (with the aim of defining the zones that have disappeared and those that remain), urban areas (and related progressive expansion), areas under cultivation (with particular attention for the zones affected by the land reforms). 
Therefore, the evolved state is described using the comparison between two representations of the state of the territory that are 60 years apart, using two different types of data:

- the Molise's regional Vegetation Map drew up after the World War II (about 1954). This is a numeric map in polygonal vector format and has different classifications for each of the two different periods.

- $\quad$ the Corine Land Cover Map dated 2006.

To make this comparison it was necessary to unify the two legends and simplify them so as to obtain the following key that is valid for both periods:

- urban areas;

- agricultural areas;

- grasslands and wastelands;

- woodland areas;

- bare ground areas (mountains, coasts etc.);

- water bodies and wetlands.

From a comparison between the two it is evident that the land cover (vegetation) and use for which the terrain is destined changed significantly in about 60 years.

In order to better assess the changes and evolution it was deemed necessary to create a comparative information layer.

This comparison was made via the technique of the graphic intersection of the polygons from the two different periods, using the Arc GIS Union command. Subsequently, the incongruent polygons were 'cleaned', thus eliminating the errors caused by the approximation with which the latter were edited during the two different drawing up phases. Use was made of commands such as Multipart to Singlepart (which even allows the identification in the table of the attributes of two or more nonadjacent polygons having the same type of attribute in common) and Dissolve (which allows the fusion of one or more adjacent polygons with the same attribute). The coastline does not result as being the same in the two periods considered and this difference was considered worthy of note. In order to highlight this, an entry is present in the key to the comparative layer which analyses precisely the decrease or increase of the land with respect to the sea.

Therefore, the key was structured in the following way:

- increase in urban areas;

- increase in agricultural areas;

- increases in woodland areas;

- increase in bare ground;

- decrease in agricultural areas;

- decrease in woodland areas;

- decrease in bare ground;

- decrease in shoreline;

- no change.

The entry no change regards both the agricultural and urban areas. The agricultural areas are included which over the years have not been subjected to urban expansion (otherwise they would be in the 'increase in urban areas' category) or to abandonment (otherwise they would be in the 'increase 
in woodland areas' category). Quantitatively this is the predominant situation and it appears as 'white' in the temporal comparison. All the polygons relating to the urban centres are collocated in this same category, as in the study area there are no built up areas that were subsequently abandoned (in fact, there is no entry for 'decrease in urban areas').

\section{SIGNIFICANT CHANGES IN DEMOGRAPHIC AND ECONOMIC SETTLEMENT}

The transformation process of the coastal areas of the Molise region began only in the early years of the last century after the remediation measures [26] and since then the area has undergone a rapid process of social and economic growth. In this regard, the analysis highlights a strong population growth between 1951 and 2011: the number of residents, in fact, almost doubled (+25.939 units) and concerned mainly the town of Termoli. After the demographic growth, the population density of the area increased from 93 inhab./sq $\mathrm{km}$ in 1951 to 193 inhab./sq $\mathrm{km}$ in 2011 and seems to be quite high if compared to the regional one (72 inhab./sq km). The data show, between 1961 and 2011, a clear centralization of the population in the urban centres, while the number of rural residents decreased drastically; in 2011, the residents of urban centres were about 45.000 units (nearly $90 \%$ of the total population). The changes in demographic structure produced impacts on housing stock and, consequently, on the land use of the area. Over the period 1971-2011, there is a continuous increase of housing (+24.440 dwellings). The houses in use by residents showed, however, a minor increase (+11.300 units), compared to houses with non-residents inside (+13.050 units). In fact, the incidence of dwellings occupied by non-residents records a high growth in the censuses of the 1970s and 1980s (from $21 \%$ to $46 \%$ ) and is strengthened in the last reference year (about 60\%). It is useful to remember that in the town of Campomarino, the houses with non-residents living inside make up more than three-fourth of the total dwellings. This highlights a situation where the growth of tourism wasn't joined, probably, by a proper hotel accommodation and therefore a sometimes excessive building process developed, followed by abusive building in some areas. The increase of housing led to a significant land use: the surface covered by dwellings has risen, in fact, from $666.437 \mathrm{sqm}$ in 1971 to 2.747 .552 sqm in 2011 .

In terms of production, the area shows a clear interconnection between production specialisations and the towns where higher levels of employment are recorded. A significant data is related to the importance of industrial activities (mechanics, agro-business, chemistry) and services in the town of Termoli.

Between 1961 and 2011, Istat data shed light on a significant increase in local units of industry and services. In 1961, there were hardly 1.223 Local Units. In 2011, instead, facilities went to 4.431 units. During the same period, farms recorded a minor increase compared to business operating in industry and services, confirming the diminished role of primary sector in the economy of the area. The total agricultural area and the utilized agricultural area suffer, instead, a significant reduction. In 2011, tourism supply was composed by 180 structures, with a clear prevalence of complementary ones (150 units) compared to hotels. The accommodation capacity amounts to 4.791 beds: hotels offer 1.881 beds; complementary structures have greater accommodation availability (2.910 beds). In relation to hotels, data referring to 1998-2011 point out a clear increase in number of beds $(+530$ units). Non-hotel accommodation capacity, however, shows a continuous decrease of beds in holiday villages and camping sites, while the consistency of tourism and hotel residences increases and the accommodation facilities defined environmentally friendly (agritourism, B\&B), are strengthened. The changes in manufacturing structure have obviously had an impact on employment. The number of employees between 1961 and 2011 has, in fact, significantly grown, moving from 10.020 units to 18.698 units in the last reporting year. An important fact to note is that since the 1960s there is a progressive reduction of employees in agriculture (-4.927) and consequently an increase of 
employment in industry $(+4.570)$ and services (+8.835 units). The result is a framework that highlights a clear outsourcing of manufacturing.

In short, the main changes which took place in the area during the periods under review are:

- population growth, especially those living in urban areas

- increase of dwellings, especially of homes occupied by non-residents

- increase of enterprises and employees in the industrial and service sectors

- reduction of employees in the agricultural sector and intensification of agriculture

- rise in tourism and hotel residences

- consolidation of environmentally friendly accommodations

\section{CONCLUSIONS: THE INTERDEPENDENCIES BETWEEN LANDSCAPE, NATURE AND DEMOGRAPHIC-ECONOMIC-TOURISM SYSTEM}

The results of the ACP point out a clear characterization in terms of landscape and nature of the area under study. The town of Campomarino is correlated to the highest percentages of covered Sites of Community Interest belonging to the Natura 2000 Network (T1) and related, particularly, to the SCI IT7222216 Mouth Biferno-Coast of Campomarino and IT7222217 Mouth Saccione-Remediation Ramitelli, and of rural areas important for pauses and for bird's nesting and coinciding with SCI IT7222216 which houses rare wetlands at the mouth of the river Biferno and with the middle-lower course of the same river; another important aspect is given by the value of the indicator T9. The town of Termoli is characterized by sheep tracks (T10) and by a greater development of the hydrographical net (T3). The town of Montenero di Bisaccia, in which lies a large part of SCI IT7228221 Mouth Trigno- Petacciato Coast with the largest beaches and Mediterranean pine forests and the major riparian vegetation along the watercourses, is characterized by a high coverage of natural and seminatural areas (T2), large core areas (T6) and high landscape diversity (T7). The town of Petacciato covers the major habitats belonging to priority directives (T5) and not (T4), this habitats are almost lacking in the municipality of Termoli because of its high level of human settlement and agricultural development.

The results of CCA analysis highlight the interdependencies between the explanatory variables of the four systems of reference.

In relation to the demographical system, in the Campomarino town, the variables P5 (\% residents in scattered houses), P8 (\% surface of dwellings occupied by residents) and P9 (\% surface of dwellings occupied by non-residents) are the main factors which impact on the areas included in the Nature 2000 Network and on the IBA (Important Bird Areas). In the town of Montenero di Bisaccia, the major factor impacting on the natural ecosystems are the average dimension of dwellings (P10), the surface of dwellings unoccupied by residents (P9) and the number of those occupied by residents (P6). In the municipality of Petacciato the pressure on habitats is mainly linked to the presence of residents in scattered villages ( $\mathrm{P} 4)$, while in the municipality of Termoli, which has the greatest population density (P2), the major number of residents (P1) of which a large part lives in the city centre, the impact is minimal because of the low coverage of natural and semi-natural areas.

In relation to the economic system (agriculture, industry and services), the town of Termoli is the heart of the local economy: it has in fact the greatest number of Local Units (E6), the highest percentage of employees in services sector (E8), and with regard to the agricultural sector, the largest number of farms (E1) and the highest ratio utilized agricultural area/total agricultural area (E4). In the towns of Campomarino and Montenero di Bisaccia the impacts on landscape and nature are due to the agricultural intensification expressed by the values of the indicators E2 and E4. 
Table 2: Summary report of the factors of pressure on landscape and nature.

\begin{tabular}{|c|c|c|c|}
\hline & \multicolumn{3}{|c|}{ Factors of pressure } \\
\hline & $\begin{array}{l}\text { Demographic } \\
\text { system }\end{array}$ & Economic system & Tourism system \\
\hline $\begin{array}{l}\text { Areas included in Nature } \\
2000 \text { Network }\end{array}$ & P5; P8; P9 & $\mathrm{E} 2 ; \mathrm{E} 4$ & L9 \\
\hline $\begin{array}{l}\text { Corine areas of natural } \\
\text { and semi-natural class }\end{array}$ & P9; P6; P10 & E2; E4; E5 & L3; L5; L13; L14; L20; L21 \\
\hline Hydrographic net & $\mathrm{P} 1 ; \mathrm{P} 2 ; \mathrm{P} 3$ & E1; E4; E6; E8 & L1; L2; L3; L4; L10; L17; L22 \\
\hline $\begin{array}{l}\text { Areas affected by direc- } \\
\text { tive (CE 43/92) habitats }\end{array}$ & $\mathrm{P} 4$ & E4; E5 & L19 \\
\hline $\begin{array}{l}\text { Areas affected by priority } \\
\text { directive habitats }\end{array}$ & P4 & E4; E6 & L19 \\
\hline $\begin{array}{l}\text { Largest homogenous } \\
\text { natural forest (CLC III } \\
\text { lev) }\end{array}$ & P9; P6; P10 & E2; E4; E5 & L3; L5; L13; L14; L20; L21 \\
\hline $\begin{array}{l}\text { Landscape diversity } \\
\text { (evenness) }\end{array}$ & P9; P6; P10 & E2; E4; E6 & L3; L5; L13; L14; L20; L21 \\
\hline $\begin{array}{l}\text { IBA (Important Bird } \\
\text { Areas) }\end{array}$ & P5, P6, P9 & E2; E4 & L9 \\
\hline $\begin{array}{l}\text { Intensive agricultural } \\
\text { area }\end{array}$ & P5; P8; P9 & $\mathrm{E} 2 ; \mathrm{E} 4$ & L9 \\
\hline $\begin{array}{l}\text { Conserved sheep track } \\
\text { surface }\end{array}$ & $\mathrm{P} 1 ; \mathrm{P} 2 ; \mathrm{P} 3$ & E1; E4; E6; E8 & L1; L2; L3; L4; L10; L17; L22 \\
\hline
\end{tabular}

Moving on to the tourism system, the town of Termoli, stands out for the highest correlations with most of the indicators used for the characterization of the system which impact especially on the preservation of the sheep tracks surfaces.

In Petacciato, a significant presence of bathing facilities (L17) is shown, an element that is in conflict with the conservation of coastal dune habitats which are particularly widespread in the town, while the highest percentage of beds in bed \& breakfast (L16) fits better with the needs of landscape and nature conservation. In the municipality of Campomarino a high environmental impact on IBANature 2000 Network due to second houses is recorded. In the town of Montenero di Bisaccia, the largest accommodation capacity (L3), here mostly linked to non-hotel accomodations (L5) and particularly to camping sites (L13, L20, L21) and to tourism and hotel residences (L14), is the major factor impacting on natural, semi-natural (T2) and core areas (T6), while the presence of agritourism (L12) ensures high landscape diversity (T7) following a tourism development model more based on environmental sustainability.

The factors of pressure on landscape and nature are shown in Table 2.

As a result of our above consideration, this work claims to have provided a new contribution to environmental and landscape, assessments of which necessarily must be taken into account for any intervention in such sensitive areas. 
Our methodology, therefore, could be used by Local Authorities, because these criteria could represent guidelines usable for conservation, sustainable development or requalification, as well as the new Code of Cultural Heritage and Landscape requires (Cialdea, 2012).

\section{REFERENCES}

[1] European Commission, Establishing a framework for maritime spatial planning and integrated coastal management, Bruxelles, 2013.

[2] Worm, B., et al., Impacts of Biodiversity Loss on Ocean Ecosystem Services. Science, 314, pp. 787-790, 2006. doi: http://dx.doi.org/10.1126/science.1132294

[3] Addis, D., et al., La gestione integrata delle Zone Costiere: strumenti di governance per le Aree Marine Protette. In: Marino D. (a cura di), Le aree marine protette in Italia, Milano, Franco Angeli, 2011.

[4] UNEP, Mediterranean Action Plan, Ecosystem Approach in the Mediterranean, Paris, 2013.

[5] MATT, Italian National Report on the implementation of ICZM based on the EU.

[6] European Commission, Defining, measuring and evaluating carrying capacity in European tourism destinations, Brussels, 2001.

[7] Daugstad, K., Negotiating landscape in rural tourism. Annals of Tourism Research, 35(2), pp. 402-426, 2008. doi: http://dx.doi.org/10.1016/j.annals.2007.10.001

[8] Dematteis, G. \& Governa, F., Il territorio nello sviluppo locale. Il contributo del modello SLoT. In: Dematteis G., Governa F. (a cura di), Territorialità, sviluppo locale, sostenibilità: il modello SLoT, Milano, Franco Angeli, 2005.

[9] Turri, E., Il paesaggio degli uomini. La natura, la cultura, la storia, Bologna, Zanichelli, 2003.

[10] Antrop M., Why landscapes of the past are important for the future. Landscape and Urban Planning, 70, pp. 21-34, 2005. doi: http://dx.doi.org/10.1016/j.landurbplan.2003.10.002

[11] Di Marzio, P., Di Martino, P., Giancola, C. \& Mastronardi, L., Il Basso Molise. In: Tassinari P., (a cura di), Le trasformazioni dei paesaggi nel territorio rurale: le ragioni del cambiamento e possibili scenari futuri, Roma, Gangemi, 2008.

[12] Mastronardi, L., Le analisi delle trasformazioni del paesaggio rurale: discussione dei risultati. Il sistema socioeconomico e demografico: Il Basso Molise. In Tassinari P. (a cura di), Le trasformazioni dei paesaggi nel territorio rurale: le ragioni del cambiamento e possibili scenari futuri, Roma, Gangemi, 2008.

[13] Forleo, M., Giaccio, V. \& Mastronardi, L., L'Agricoltura nel sistema socioeconomico territoriale del Basso Molise. In: Carrabba et al. (eds.) Il Progetto DINAMO per la Biodiversità del Molise, ENEA, Roma, 2011.

[14] Cialdea, D., Il Molise, una realtà in crescita, Milano, Franco Angeli, 1994.

[15] Mastronardi, L. \& De Gregorio D., Il fenomeno della stagionalità e le conseguenze sull'ambiente. In: Meini M. (a cura di), Il turismo al plurale. Una lettura integrata del territorio per un'offerta turistica sostenibile, Milano, Franco Angeli, 2012.

[16] Belfiore, S., Balgos, M., McLea, B., Galofre, J., Blayde, M. \& Tesch, D., A Reference Guide on the Use of Indicators for Integrated Coastal Management. ICAM Dossier 1, IOC Manuals and Guides No 45. UNESCO, Paris. 2003.

[17] EUCC, The Coastal Union 2006. Measuring Progress in the Implementation of Integrated Coastal Zone Management: Guidelines for Completing the Progress Indicator. EU Working Group on Indicators and Date, 2006.

[18] Pelletier, D., García-Charton, J.A., Ferraris, J., David, G., Thébaud, O., Letourneur, Y., Claudet, J., Amand, M., Kulbicki, M. \& Galzin R., Designing indicators for assessing the effects 
of marine protected areas on coral reef ecosystems: A multidisciplinary standpoint. Aquatic Living Resources, 18, pp. 15-33, 2005. doi: http://dx.doi.org/10.1051/alr:2005011

[19] Pomeroy, R.S., Parks, J.E. \& Watson, L.M., How is your MPA doing? A guidebook of natural and social indicators for evaluating marine protected area management effectiveness. IUCN, Gland, Switzerland and Cambridge, 2004. doi: http://dx.doi.org/10.2305/iucn.ch.2004. paps.1.en

[20] Stern, M.J., Measuring conservation effectiveness in the marine environment: a review of evaluation techniques \& recommendations for moving forward. The Nature Conservancy, 2006.

[21] UNWTO, Indicators of Sustainable Development for Tourism Destination, Madrid, 2004.

[22] Hotelling, H., Relations between two sets of variants. Biometrika, 28, pp. 321-377, 1936. doi: http://dx.doi.org/10.1093/biomet/28.3-4.321

[23] DECRETO LEGISLATIVO - 26 marzo 2008, n. 63 Ulteriori disposizioni integrative e correttive del decreto legislativo 22 gennaio 2004, n. 42, in relazione al paesaggio.

[24] Cialdea, D., A new landscape planning approach to areas with a strongly rural matrix, ed. M. Campagna, Planning Support Tools Policy Analysis, Implementation and Evaluation, Milano: Franco Angeli Editore, 2012.

[25] Cialdea, D. \& Maccarone A., Territory diachronic maps for the Regional Landscape Plan, ed. M. Campagna, Planning Support Tools Policy Analysis, Implementation and Evaluation, Milano: Franco Angeli Editore, 2012.

[26] Nola, L. \& Orlando, F., Termoli: dove atterra la Fiat. In: Barberis C., Dell'Angelo G.G. (a cura di), Italia rurale, Bari, Laterza, 1988. 